\author{
DANIJEL DŽINO \\ Macquarie University, Sydney \\ danijel.dzino@mq.edu.au

\section{APPIAN'S ILLYRIKE: THE FINAL STAGE OF THE ROMAN CONSTRUCTION OF ILLYRICUM}

\begin{abstract}
Appian's Illyrian book (Illyrike) was originally intended to be just an appendix to his Macedonian book and today remains the only extant ancient work dealing with the early history of Illyricum which is preserved in its entirety. In this short work Appian puts together different local and regional histories in order to create a unified historical narrative and determines the historical and mythological coordinates of Illyricum inside the ancient world. This paper will discuss Illyrike in the context of the Roman construction of Illyricum as a provincial space, similar to some other regions in continental Europe such as, for example, Gaul or Britain. They were all firstly created through the needs of Roman political geography and later written into literary knowledge through the works of ancient history and ethnography. This paper will argue that Appian's Illyrike represented the final stage of the Roman construction of Illyricum from an imaginary to a provincial space, which was the point of its full coming of age as an integral part of the ancient world and the Roman Empire.
\end{abstract}

Keywords: Appian, Illyricum, Roman empire, imperial geography.

$\mathrm{P}$

ower and knowledge are inextricably connected and intertwined - they feed on each other and create each other, as Foucault famously observed. ${ }^{1}$ We can establish the existence of this peculiar symbiosis between power and knowledge in many past and present contexts, especially as an impact of power-relations on the construction of discourses and their subsequent control and maintenance. The knowledge, contact, conflict and conquest of the 'Other' are different, but are also complementary strategies of intercultural interaction in the past. The systematization of knowledge of the conquered 'Other' has a special position amongst them as it enables the conqueror, who controls written discourse, to strengthen political domination or military conquest by intellectually conquering the conquered. ${ }^{2}$ More recent scholarship in Roman history convincingly showed the existence of links between intellectual and territorial dominions in Roman thought by revealing different strategies employed by the Romans to intellectually master the spaces both outside and inside their political influence. Caesar's Commentaries on the Gallic Wars

\footnotetext{
${ }^{1}$ E.g. Foucault 1980.

${ }^{2}$ It is sufficient to mention Said's 'Orientalism', with all of its positive and negative aspects, Said 1978, or the more recent work of Todorova 1997.
} 
is a perfect example of intellectual conquest for a careful reader as his 'artful reporting' perfectly complemented the brute force of his legions. ${ }^{3}$ Tacitus' Germania and Agricola are also prime examples of the Roman intellectual and literary conquests of the 'Others'; so too is Strabo's Geography and geographical sections of Pliny's Natural History. ${ }^{4}$

Appian's Illyrian book (Illyrike) was originally intended to be just an appendix to his Macedonian book. Today, this appendix remains the only extant ancient work dealing with the history of Illyricum preserved in its entirety. In Illyrike, Appian combines different local and regional histories in an attempt to create a basic historical narrative and to determine the historical and mythological coordinates of Illyricum within the ancient world. ${ }^{5}$ This paper will discuss Illyrike in the context of the Roman construction of Illyricum as a provincial space, similar to some other regions of the Empire, such as Gaul, Germany, Spain or Britain. These regions were created as such through the logic of military conquest. Later, the Roman administration reorganized recently conquered territories by measuring the land, counting inhabitants, and demarcating borders of new imperial possessions - from provinces to the smallest communities. This 'second stage' of the conquest broke old local ethnic and cultural networks, establishing new social realities for conquered peoples. It also established a new cognitive arrangement of space that affected the ways in which intellectual elites perceived the geography of the Empire. ${ }^{6}$ Early imperial historians, geographers and ethnographers gradually wrote those 'imperial artifacts' into the literary knowledge that would be transmitted to Late antiquity and even further. Carefully and respectfully they reassembled the existing knowledge of these regions in order to fit their works into a new imperial ideological worldview. ${ }^{7}$

Appian was not living in the times of imperial expansion or in the times when imperial conquests were organized into new territorial and geographical units. The emperors ruling during his life changed the paradigm on which the Roman empire existed - it was not a conquest but integration and consensus within the Empire that Hadrian and Antoninus Pius strived for. The Empire turned inside, seeing itself as a finished product of all earlier conquests. Appian was certainly not immune to those winds of change blowing in his time, being too close to those in power as priest of the cults of Venus and Roma appointed directly by Hadrian and imperial procurator. A new policy of the Roman emperors affected the composition of his Roman History equally as the Roman passion to catalogue the Empire as a collection of different more or less civilized peoples who pay tribute and enjoy the Roman peace. ${ }^{8}$

This paper will argue that Appian's Illyrike represented the final stage of the Roman

${ }^{3}$ Powell, Welch 1998; cf. Riggsby 2006; Krebs 2006; Schadee 2008; Osgood 2009.

${ }^{4}$ Germania: Lund 1991; O’Gorman 1993; Agricola: Rutledge 2000; Clarke 2001; Strabo: Clarke 1999: 193-336; Pliny: Evans 2005; Gaul: Woolf 1998: 54.

${ }^{5}$ On Illyrike the ultimate work is Šašel Kos 2005. See also Marasco 1993, and the first in-depth study of Dobiáš 1930.

${ }^{6}$ Nicolet 1991, for Roman reorganization of space in the early Principate, see also Purcell 1990; Ando 2000: 6162, 351-356; Tallbert 2004.

${ }^{7}$ See also Stewart 1995 (Britain); Cruz Andreotti, Le Roux, Moret 2006 (Spain) and the works cited in n. 4 above.

${ }^{8}$ Osgood 2015, cf. Ando 2000: 330-332. Appian as the priest of Venus and Roma - Brodersen 2015; Appian as imperial procurator - App. Hist. Rom., Praef. 15.62. 
construction of Illyricum by providing a 'historical biography' of this area - from mythological origins to the Roman conquest. The policies of his times were embedding new views of the Empire as a complete entity that should have been just the way it was in the $2^{\text {nd }}$ century, creating new mental templates for its inhabitants and intellectual elites to perceive the world and their place in it. So, if the empire was considered as a finished work, that certainly related to all of its parts, the provinces and the regions created by the Roman administration. The change of mental templates changed social realities, so it is not surprising that literary intellectual elites of the Empire should have felt a need to describe them. This is exactly what we see in Appian's dissatisfaction with the chronological approach to history in earlier Graeco-Roman historiography and his conceptual statement from the beginning of the Roman History that he intended to "describe the boundaries of the peoples (i.e. provinces) ${ }^{9}$ Romans rule." 10 A few matters will be discussed in order to present this argument: the development of the term 'Illyricum' in Roman political and literary discourse, earlier literary attempts to integrate this region within the corpus of ancient knowledge, and literary and intellectual strategies used by Appian to depict the region.

\section{Illyricum}

There are a few points that should be made in order to better understand the development of ancient intellectual and public discourse concerning Illyricum. In short, Illyricum was the creation of Roman imperialism; it did not exist as such in Hellenistic geography or Roman political discourse before the infamous lex Vatinia de imperio Cesaris. This law brought about the creation of Illyricum from existing Roman allies and tributepaying communities on the eastern coast of the Adriatic and attached it to Caesar's proconsular command (provincia) of Cisalpine Gaul. ${ }^{11}$ The law resurrected the term 'Illyricum', which probably derived from regnum Illyricum, the Roman term for a Hellenistic-era indigenous polity in the south-eastern Adriatic, dissolved in $167 \mathrm{BC}{ }^{12}$ The terms 'Illyrians' (Illurioí) and 'Illyria' (Illuría, Illurís) were originally Greek terms, which described their western non-Hellenophone neighbors and were far from being an accurate describer of their shared identity. ${ }^{13}$ Imagining the population of the Western Balkans as 'Illyrians' stems from several different identity-discourses originating in Early Modern and later periods that reinterpreted ancient perceptions of this area. Archaeology shows there the existence of several distinct regional networks between small Iron Age communities ('archaeological cultures') that were homogenizing into different political alliances after ca. 400 BC. ${ }^{14}$ In the period between the dissolution of the Illyrian kingdom and the lex Vatinia, 'Illyricum' was just one of the terms used to describe the frontier zone developing between

9 Tallbert 2004: 24-25. Under the Greek words ethnos and eparcheia are understood Roman provinces, Mitchell 2000: 125-126.

${ }^{10}$ App. Hist. Rom. Praef. 1-2, see Rich 2015: 69-72 on Appian's conceptual approaches.

${ }^{11}$ Dzino 2010: 80-84; cf. Šašel Kos 2005: 335-340 and earlier Wilkes 1969: 37-38.

12 Šašel Kos 2000: 284.

13 Šašel Kos 2005: 219-239; Matijašić 2011; Dzino 2014.

${ }^{14}$ Dzino 2014a (early modern and modern perceptions); Dzino 2012 (Iron Age communities). 
northern Italy and Macedonia/Epirus. Another contemporary alternative term such as Dalmatia was derived from the term Delmatae/Dalmatae describing an indigenous political alliance from the central Dalmatian hinterland from the $3^{\text {rd }}$ century BC. ${ }^{15}$

The construction of Illyricum and its function as the administrative region of the Empire were mutually complementary tasks. Both, the formation and northward extension of Illyricum in Roman military conquests from the late $1^{\text {st }}$ century BC to the early years of $\mathrm{AD}$, created a wider Illyricum - a new 'imperial artifact' which now stretched all the way to the river Danube and the Pannonian plains. Soon after the Batonian war (AD 6-9), this space was arbitrarily divided into the provinces of Dalmatia and Pannonia (or Illyricum superius and inferius) by the imperial administration. ${ }^{16}$ In Appian's time Illyricum was a loose term. It usually described a wider Illyrian tax-zone (portorium Illyrici et ripae Thraciae), which included the provinces of Raetia, Noricum, Pannoniae (Superior and Inferior), Dacia, Dalmatia and Moesia Superior. The term was to be resurrected and selfappropriated by the new military elite of the Danubian legions (Illyriciani) in the $3^{\text {rd }}$ century and its administrative comeback as the Illyrian diocese in the $4^{\text {th }}$ century. ${ }^{17}$

\section{Predecessors}

Appian's statements regarding his inability to either locate much about Illyricum in the sources or to determine how certain events happened helped to prolong his low credibility in earlier scholarship. ${ }^{18}$ Appian himself said that his Illyrian excursus was not planned originally, but that it came about because he wanted to describe Octavian's campaigns in that area in more detail. However, he was visibly struggling both to find reliable sources and to re-position this 'unfortunate' mass of space between the Danube and the Adriatic anywhere else. ${ }^{19}$ There is no need to blame Appian for not locating suitable sources. It is very probable that previously no-one had written anything about the history of Illyricum for quite good reasons: Illyricum did not exist before Caesar as a well-defined political term, or before Augustus as a more-or-less well defined spatial term. So, it seems reasonable to assume that earlier scholarship prior to the establishment of Roman Illyricum in the early Principate was unable to see this area as a unified territory. For this reason, Appian's sources wrote only about its regions, but within very different spatial and ethnographic contexts.

Early works of Greek geographers such as Hecataeus, Ephorus, Erastotenes or maritime itineraries (the periploi of pseudo-Scylax, pseudo-Skymnos) were interested in the length and descriptions of the eastern Adriatic coast and basic indigenous ethnography mostly focusing on the coastal communities. ${ }^{20}$ There were also anecdotes and stories

\footnotetext{
${ }^{15}$ See Čače 2003 on the development of the term Dalmatia.

${ }^{16}$ See Dzino 2010: 159-162 with literature, and recently Kovács 2014, 15. On the names of those provinces immediately after the division see opposite views in Šašel Kos 2010 and Kovács 2014: 40-57.

17 Šašel Kos 2005: 243-245, and also Gračanin 2005 for a loose perception of Illyricum in writings from the $2^{\text {nd }}$ and $3^{\text {rd }}$ centuries $\mathrm{AD}$.

${ }^{18}$ See Marasco 1993: 463-464 and Šašel Kos 2005: 48-51 for earlier opinions.

${ }^{19}$ BCiv 5.145, cf. Illyr. 6.16.

${ }^{20}$ Wilkes 1969: 1-7; Kozličić 1990; Šašel Kos 2005: 235-237; Dzino 2014; Matijašić 2015.
} 
circulating in the literary sources, such as stories about fighting between the indigenous groups of the Ardiaei, Autariatae, Triballi and Scordisci. ${ }^{21}$ One very popular story narrates the unusual plague of frogs and mice, which forced the Autariatae to look for a new homeland. ${ }^{22}$ The Greeks also tried to incorporate this region within a mythological realm through several different stories, the most famous being the myths of Cadmus and Harmonia, Diomedes, and the travels of the Argonauts. ${ }^{23}$ At the beginning of the $1^{\text {st }}$ century BC Alexander Polyhistor wrote the now lost treaty on Illyria. Its date of composition, however, shows that it can only represent an Illyria of Hellenistic times, corresponding with the borders of the former Illyrian kingdom, as Roman Illyricum had not yet existed. ${ }^{24}$ Posidonius also wrote about the region, but it is impossible to deduct anything useful from the preserved fragments besides his interest in the people of Scordisci and that he or his sources perceived Dalmatia as a separate region. ${ }^{25}$

In late Augustan and early Tiberian times Strabo of Amasia was the first ancient author that we know of who actually wrote about Illyricum using recently developed Roman political terminology and colonial projections of the freshly conquered regions. He was born and educated within the Greek culture, but in the Geography his Greekness is counterbalanced by a sense of belonging to the Roman empire and the zeitgeist of the new imperial ideology. ${ }^{26}$ Strabo's account of Illyricum draws material from Hellenistic geographic and ethnographic traditions, but also from more recent events such as Octavian's campaign or the Batonian war. He incorporates Illyricum within the framework of Augustan imperial discourse and as an essential part of the Empire. Strabo appropriates Roman imperial terminology as the main descriptive tool in the forms Illurída or tá Illurika (the Illyricums, i.e. Dalmatia and Pannonia). In accordance with his conceptual methodology, Strabo shapes Illyricum as a region in transition from barbarism to civilization: with Roman help it progresses towards civilization, but has not attained it yet. ${ }^{27}$ Besides Roman interactions with the region, Strabo cares little for the history and past of Illyricum probably leaving it for his lost History. His main purpose is description - geographic and ethnographic. However, it is not too much to claim that Strabo's work reveals the beginnings of a literary-intellectual discourse developing upon newly conquered regions of the Empire,

\footnotetext{
${ }^{21}$ Mir. ausc. 138; Ar. Byz., Epit. 2.560; Theopomp. ap. Ath. 6.271e (=FGrH 115 F40); Strabo 7.5.11, mentioned by Appian in Illyr. 3, see below.

${ }^{22}$ Heraclides Lembus ap. Phylarchus (FGrH 81 F 4) - first half of the $2^{\text {nd }}$ century BC: the plague of frogs somewhere near Paeonia and Dardania; Agatarchides of Cnidus ap. Photius, Biblioth. 250.59 - mid-second century BC: the frogs drove out the Autariatae; Diod. Sic. 3.30.3; Ael. NA 17.41; Just. Epit. 15.2.1; Oros. 3.23.36-7. Appian also uses the story in Illyr. 4-5, see Šašel Kos 2005: 190-198, and also below.

${ }^{23}$ E.g. Šašel Kos 1993; Ead. 2004; Ead. 2005: 115-120; Katičić 1995; Rossignoli 2004; Castiglioni 2006; Ead. 2010. See also Castiglioni 2007 for the role that myths played in acculturative processes between the indigenous peoples and the Greek colonists in the eastern Adriatic, and in comparable perspective Malkin 2002; Riva 2010.

${ }^{24}$ Alex. Polyh. ap. Val. Max. 8.13.7 and Plin. HN 7.155 (FGrH 273 F 17), see Sterling 1992: 144-152 on Polyhistor.

${ }^{25}$ Posidonius, FGrH 87 F 19, 31, 48 (=Kidd Fr. 70, 272, 240a), see Clarke 1999: 366-367 on unreliability of the passage on Dalmatia for any definite conclusions.

${ }^{26}$ Clarke 1997: 109-110; Ead. 1999: 335-336. His view of the Romans is sometimes critical and even dismissive, but Strabo's work is visibly affected by the new views on the empire in Augustan times, Dueck 2010: 243-246.

${ }^{27}$ Dzino 2006; Id. 2008, see also Marion 2006 and Šašel Kos 2011 with somewhat different views.
} 
incorporating Hellenistic ethnography and geography within the new imperial worldviews.

Pliny's literary projection of Illyricum appears a few decades after Strabo. He does not use the term Illyricum frequently and when he does it is mostly in the sense of Augustan Illyricum. Elsewhere, he focuses his attention on the administrative provinces of Dalmatia and Pannonia which were brand new spaces created by Roman administration and colonial rule in early Tiberian times and in Pliny's time gradually replacing the term Illyricum. Pliny also catalogues indigenous peoples, recording lists of provincial cities, Roman colonies, peregrine civitates with their decuriae and administrative conventus in Dalmatia. In Pannonia, he listed Roman colonies and peregrine civitates. ${ }^{28}$ While Strabo observed Illyricum as a freshly made and still partly amorphous artifact - Pliny describes Illyricum looking into the 'second stage' of the conquest, when provincial landscapes were already transformed by the instruments of the empire.

\section{Appian’s composition}

Appian states that his aim is to describe how the Romans conquered the peoples from this region. ${ }^{29}$ However, his narrative is not only a catalogue of the Roman campaigns, but also an attempt to define and fully incorporate the region within the corpus of ancient knowledge. Illyrike was a highly structured work and it can be divided into several main sections. For this paper of crucial importance are the narrative strategies employed in his ethnographic introduction, chapters one to five, and his description of Roman Illyricum in chapter six. ${ }^{30}$ The introduction begins with the Greek definition of the geographic space and its inhabitants, followed by the mythology, pre-Roman past, the Roman definition of the space and its inhabitants, and finally by the narrative of the Roman conquest, which occupies the rest of the book.

In the opening section, Appian defines the space he is going to write about. Illyricum is probably the most artificial of all Roman 'colonial artifacts' in western Europe, a very loose space for which we cannot pinpoint a certain political institution, a shared sense of identity amongst the indigenous population, or clear geographical markers. To make things even more difficult for Appian, the term Illyricum was used in different circumstances and was manipulated for different reasons in the past, as we saw earlier. Geographical features are much more helpful in defining areas such as Hispania, Britain, or Italy for example. Most of Appian's 'ethnic' books deal with more or less well-defined political units, whose rulers were waging wars with the Romans. There was no controversy in defining these realms, nor any need; it was the extent of the power of their rulers which defined them and their defeat or capitulation would clearly signify Roman conquest. ${ }^{31}$ The only other preserved book which depicts the creation of 'imperial artifacts', or the conquest of a politically and culturally heterogeneous space, is Iberike (Keltike and Dakike may have been additional cases, but the former is fragmentary and the latter was either lost, or indeed, never

\footnotetext{
${ }^{28}$ Plin. HN 3.129-52, see Marion 1998, and Domić-Kunić 2004 for Pliny’s sources.

${ }^{29}$ BC 5.145 .

${ }^{30}$ See Šašel Kos 2005: 85-89 for a schematic structure of Illyrike.

${ }^{31}$ Marasco 1993: 487-489, cf. Gómez Espelosín 1993: 427.
} 
written). Iberike shares some similarities with Illyrike, especially in regard to the definition of space and early history. There, Appian defines Hispania easily by physical features alone: the encircling sea and the Pyrenees, which divide it from Gaul. ${ }^{32}$

At the beginning, Appian does not mention Illyricum at all - he does not mention it until chapter six - but rather at the very beginning defines the space using the Greek perception of the indigenous population as 'Illyrians': 'The Greeks define as Illyrians those peoples ....' So Appian, like the Greek ethnographic tradition before him, replaced heterogeneity of local communities with the singularity, 'Illyrians'. This invented pseudoethnic singularity simplifies the region for his audience as a single unit of historical analysis. ${ }^{33}$ In the west his 'Illyrians' are defined with the limits imposed by physical features (the Adriatic, the Danube, the Alps) and ethnographic exclusion (non-Paeonians i.e. nonPannonians) ${ }^{34}$, while in the east they are defined only by ethnographic exclusion (nonThracians, non-Greeks, non-Macedonians). The measures given as the longitude $(6,000$ stades) and latitude (1,200 stades) of the space which Appian populates with the 'Illyrians' are ascribed to the Romans and probably originate from different sources - Greek and Roman. ${ }^{35}$ The length of 6,000 stades given for the Illyrian coast indeed fits with Strabo's $(5,800$ stades $)$, which was probably taken from Polybius, as Kozličić argued. However, the width of Appian's Illyricum of 1,200 stades (ca. $222 \mathrm{~km}$ ) is almost an exact measure of the distance between Salona and Servitium (154 Roman miles, i.e. 1,232 stades) coming from the Antonine Itinerary. ${ }^{36}$ This represents the length between Salona and the DalmatianPannonian provincial border in the valley of the Sava river, coinciding in part with Dolabella's road colonia Salonitana ad fines provinciae Illyrici built between AD 14 and $20 .{ }^{37}$

After that, Appian uses mythology which enables him to embed the space he earlier defined within the most ancient 'history'. Appian did something similar in Libyke, narrating the foundation-story of Carthage, or in Mithridatike, citing Homer, but not in Iberike, perhaps because no familiar story existed for his audience. ${ }^{38}$ The myth that Appian mentions places the population of Illyricum on an equal level with the Celts and Galatians, as Illyrius, the eponymous ancestor of the Illyrians, was together with Celtus and Galas the offspring of the Cyclops Polyphemus and nymph Galatea. ${ }^{39}$ This myth links Sicily with future

\footnotetext{
32 Iber. 1, see Gómez Espelosín 1993.

${ }^{33}$ Cf. Marasco 1993: 485.

${ }^{34}$ Appian strangely mixes up Paeonians from modern-day FYR Macedonia with the Pannonians, Šašel Kos 2005: 108-110.

35 Illyr. 1. Šašel Kos 2005: 97-114 follows Kozličić (1990: 209-217) in the opinion that Appian’s 'Roman' measures pre-date the conquest.

${ }^{36}$ Itin. Ant. 268.1-269.7. The Antonine Itinerary post-dates Appian, but it is clearly a compilation of earlier Roman itinerary data from publicly displayed tabellaria, see Salway 2001.

${ }^{37}$ CIL 3.3198a=3.3200, see also CIL 17/4: 130-133 on Dolabella's roads. Dolabella's road is a bit longer, so it is possible that Antonine Itinerary follows some later-built shortcut, see Bojanovski 1974: 41-129. Bojanovski (1974: 42) wrongly calculated the length of the distance between Salona and Servitium from the Antonine Itinerary as 149 instead of 154 Roman miles.

${ }^{38}$ Lib. 1; Mithr. 1.

${ }^{39}$ Illyr. 2, probably derived from Timaeus (FGrH 566 F 69), Šašel Kos 2005: 120-132. There might be another link between the Cyclopes and this region. It has been argued that late Bronze Age Aegean contacts with the
} 
Illyricum and it has been suggested by Castiglioni that it was the product of propagandistic discourse emulating from the Syracusan tyrant Dionysius in the early $4^{\text {th }}$ century BC, appropriating and manipulating the origins of Illyrius from the existing parallel myth of Cadmus and Harmonia who were also considered to be the parents of Illyrius. ${ }^{40}$ Outside of the original context, the myth enables Appian to insert order into ethnographic inconsistency and chaos. He also relates the heterogeneous indigenous population of Illyricum to a common ancestor who is located within the ancient mythological past.

The section on the mythological past is followed by the pre-Roman past. This part selectively presents some indigenous groups, emphasizing their mutual rivalries: the Triballi and Scordisci, or the Autariatae and Ardiaei, with a mention of the Liburni, the sea-people and the alleged pirates from the north-eastern Adriatic. The narrative section establishes the picture of the indigenous peoples in pre-Roman times as a war-like bunch, prone to piracy and in perpetual conflict with each other - painting a very similar picture of pre-Roman Illyricum to Strabo. ${ }^{41}$ It is followed by the story of the 'Illyrian' raid on Delphi and Apollo's curse, which is a curiously distorted version of the past as it brings together several unrelated historical events. Appian inserts two raids on Delphi in the narrative: one in 279 BC by the large group referred to as the Galatae and often represented as the ancestors of the Scordisci; the other in 84/83 BC by the Thracians and Scordisci, together with the invasion of the Cimbri and Teutones in the late $2^{\text {nd }}$ century BC, and the Roman wars with the Scordisci. The story tells us that the Autariatae were punished by Apollo with madness, so they joined the first raid on Delphi. Returning home, the god punishes them with a plague of frogs for their participation in that sacrilegious raid. After that punishment, the 'Illyrians', together with the remainder of the Cimbri and Teutones, still could not refrain from further plundering temples in Greece, so they are again 'rightfully' punished, this time by the Roman armies and their commander Lucius Scipio Asiagenes. However, the power of gold plundered from Delphi blinded even a Roman commander who accepted it as a bribe and thus contracted the curse of Apollo and carried it to Rome, where soon the civil wars began. ${ }^{42}$

This moralizing fable constructs a parallel historical reality, using real historical events as a basis for a story. Appian uses the term theoblábeia (infatuation sent by the gods, malignant fate) as a main cause of 'Illyrian' misfortunes, and an active historical factor. ${ }^{43}$ The story, in my opinion, has three aims: to entertain his audience in the way inventio did in Roman historiography, ${ }^{44}$ to represent the subsequent Roman conquest of Illyricum as a justified punishment for morally depraved barbarians, and finally, to relate this Illyrian

then-prevalent, pastoralist societies of the eastern Adriatic used to construct the 'ethnographic' accounts of the Cyclopes reflected in the Odyssey, Mlekuž 2007.

${ }^{40}$ Castiglioni 2007: 171-177; cf. Šašel Kos 1993 and Castiglioni 2010 on Cadmus and Harmonia in Illyria.

${ }^{41}$ Illyr. 3. Strabo, 7.5.11. Strabo used his narrative technique to establish the sequence of regional political hegemons finishing with the Romans, who finally bring order. Clarke 1999: 256-257. See Dzino 2006: 124-128 for Strabo and Illyricum.

42 Illyr. 4-5; Šašel Kos 2005: 133-218, cf. Marasco 1993: 468-71. See Papazoglou 1978: 284 ff.; Popović 2005 and Delev 2013 for historical and archaeological evidence of Asiagenes’ campaign against the Scordisci.

${ }^{43}$ Gowing 1992: 16; Hahn, Neméth 1993: 393.

${ }^{44}$ For inventio see Cic. de Orat. 2.62-3; Wiseman 1981: 388-392; Potter 1999: 12-18, 135-138; Barnes 2005: 13 19. 
appendix back to the main topic of his history - Roman internal conflict.

Before beginning with the narrative of Roman conquest, Appian redefines the space once again, this time through the Roman conceptual framework of the space, determined by the portorium of Illyricum - the tax zone which stretched from the Alps to the Black sea. ${ }^{45}$ It is very similar to Cassius Dio's description, however, Dio is much less confused by the fluidity of the term. ${ }^{46}$ Here, Appian introduces for the first time the term Illyricum (Illurída, Illurikòn telos): a quintessentially Roman conceptual tool for the definition of this area. Contrasting the Greek ethicizing of indigenous communities, Roman Illyricum presented here is a typical colonial artifact constructed through Roman domination over the indigenous communities. Appian, with or without intent, nicely depicts the working of colonial geography and the language of force here. The Romans have the power to name names and to label the region in ways that suit them, which usually have nothing to do with local identity-narratives (as all other imperial powers have done and are still doing in that part of the world): '... each people is called by its own name and together they are all considered to be living in Illyricum (Illurída)'. The comparison with the Greeks that follows this statement misses the point and shows that Appian just follows the common stereotype of his times that labels the population of Illyricum as 'Illyrians' ${ }^{47}$

The historical narrative of the conquest is presented in Appian's usual manner by cataloguing Roman armies and campaigns and arranging them in relation to individual indigenous groups/polities. This gives the impression of continual and gradual low-scale conquest of the region from the First Illyrian war of 229 BC to Octavian's campaigns of 3533 BC, including a few other subsequent operations until the Alpine wars of Drusus and Tiberius. ${ }^{48}$ The most important part is dedicated to Octavian and his campaigns, sourced directly from his Autobiography. ${ }^{49}$ Octavian is the only real hero of Illyrike. Other Roman commanders do not receive much more other than naming, while the characters of indigenous leaders are bleak and mostly nameless. Appian even avoided making more elaborate literary characterizations of the 'pirate queen' Teuta, or 'treacherous' Demetrius of Pharus, both constructed as colorful literary characters in earlier historiography. ${ }^{50}$

\section{The Conclusion}

Appian's Illyrian book, like other sources from Graeco-Roman antiquity, was written by the member of the educated Mediterranean elite, a social group that controlled written

\footnotetext{
${ }^{45}$ Illyr. 6. On Illyrian tax zone see Ørsted 1985: 251-347.

${ }^{46}$ Dio, 12.49.6 (=Zonaras, 8.19), cf. Šašel Kos 1986: 88-95.

${ }^{47}$ Illyr. 6.15, see Šašel Kos 2005: 222-223.

48 Illyr. 7-30.

${ }^{49}$ Illyr. 15-28. Appian usually preferred to follow a single, the most influential source, as seen in the treatment of Polybius in the case of the Roman war with Antiochus the Great - Rich 2015. While this argument is essentially right, Appian made an exception in Illyrike and chose not to follow Polybius in the description of the Illyrian wars, App. Illyr. 7.17-10.29: Šašel Kos 2005: 249-290.

${ }^{50}$ E.g. Polyb. 2.4.7-9; 2.8.4-12; Dio, 12.49.3-5 (=Zon. 8.19) (Teuta), or Polyb. 3.16; 5.108.6-8 (Demetrius of Pharus). For the similar treatment of indigenous leaders as bleak, 'deformed mirrors', diminishing or underlining stature of the Roman leaders in Iberike, see Gómez Espelosín 1993: 405.
} 
discourse for a long time. The 'knowledge' he produced was a worldview from the imperial centre where all political power was concentrated. In the case of Illyricum, his work was describing social realities from the period of full integration of imperial peripheries - the 'third' stage in the Roman conquest, following military conquest and rearrangement of provincial landscapes. It completed the task, begun in Caesar's time, to make sense of Roman political domination over different communities in the region between Macedonia and northern Italy by constructing that space as a new geo-political singularity - Illyricum. This enabled easier political management of the region when Roman domination was later extended towards the Danube and subsequently reshaped into the provinces of Dalmatia and Pannonia.

Appian assimilates this area into the Mediterranean cultural and pseudo-historical discourse through his ethnographic introduction that invents its origins. He defines Illyricum through two different perceptions of the 'Other': Greek ethnographic perception, which invents the ethnic term 'Illyrians', and the Roman colonial construct, taking Greek terminology a step further and placing this term as a taxonomic label over a politically dominated space that cannot be defined in any other way. Appian embeds the inhabitants of Illyricum within the time-space coordinates of the Greek mythological past, describing the pre-Roman past and Roman conquest as a 'rightful' punishment for sacrilegious raids on Delphi. He bridges the gaps between different historical contexts and different Illyricums that existed in his past and present presenting Illyricum as an unchangeable singularity. What he does is to create a 'historical biography' of Illyricum projecting this singularity in the past, searching for its genesis and mythological ancestors, stories from pre-Roman times, only to finish with the description of the Roman conquest, which brought this area to 'civilization'. Appian's Illyricum is constructed similarly to Strabo's - from the pieces of discrepant pasts, glued together by the powerful force of Roman imperial ideology. In contrast to Strabo, Appian's Illyricum is not marching on its way towards civilization: it is a region included entirely in the Roman ideological network - a new 'imagined community' which unifies all the disparate local histories and geographies under the imperial umbrella.

Integration was not necessarily an equality in imperial power-sharing networks. Illyricum remains perceived as imperial periphery, epitomizing backward and primitive provinces - the attitude that we can see from the works of some authors writing after Appian, especially Cassius Dio and Herodian. ${ }^{51}$ Very soon after Appian's death, the Roman construct of Illyricum was ideologically appropriated by the Danubian legions consisting of indigenous soldiers using it to construct their own paradigm of virtus Illyrici. They would be regarded by smooth-tongued imperial panegyricists as a rough and uneducated bunch, which was nothing less than the 'best thing for the Empire'. ${ }^{2}$

\footnotetext{
${ }^{51}$ Dio, 49.36 (Pannonians as brave, bloodthirsty and primitive); Hdn. Hist. 2.9.11 (Pannonians skilful in battle, but slow-witted).

${ }^{52}$ Aur. Vic. Caes. 39.26.
} 


\section{REFERENCES:}

Ando, C. Imperial Ideology and Provincial Loyalty in the Roman Empire, Berkeley/Los Angeles, University of California Press, 2000.

Barnes, C. L. H. Images and Insults: Ancient Historiography and the Outbreak of the Tarentine War. Historia Einzelschriften 187, Stuttgart: Steiner, 2005.

Bojanovski, I. Dolabelin sistem cesta u rimskoj provinciji Dalmaciji, Djela 47/2, Sarajevo: Akademija nauka i umjetnosti $\mathrm{BiH}, 1974$.

Brodersen, K. Epitaphios: Appianos and his treasured Eutychia, in: Welch 2015, 341-350.

Castiglioni, M. P. 'Myth as an instrument for the study of Greek and indigenous identities I: Greek myths in the Illyrian area', in: J. Carvalho (ed.), Religion, Ritual and Mythology: Aspects of Identity Formation in Europe, Pisa: Edizioni Plus, 2006, 127-141.

. 'Genealogical myth and political propaganda in antiquity', in J. Carvalho (ed.), Religion and Power in Europe: Conflict and Convergence, Pisa: Edizioni Plus, 2007, 165-181.

. Cadmos-serpent en Illyrie. Itinérarie d'un héros civilisateur. Pisa: Edizioni Plus, 2010.

Clarke, K. 'In Search of the Author of Strabo's Geography', JRS 87, 1997, 92-110.

. Between Geography and History: Hellenistic Constructions of the Roman World, Oxford:

Oxford University Press, 1999.

. 'An island nation: re-reading Tacitus', Agricola', JRS 91, 2001, 94-112.

Cruz Andreotti, G., Le Roux, P. and Moret, P. (eds.) La invención de una geografía de la Península Ibérica Vol. 2: La época imperial. Actas del Coloquio Internacional celebrado en la Casa de Velázquez de Madrid entre el 3 y el 4 de abril de 2006, Málaga/Madrid: Servicio de Publicaciones del Centro de Ediciones de la Diputación de Málaga/Casa de Velázquez, 2006.

Čače, S. 'Ime Dalmacija u 2. i 1. st. prije Krista', Radovi Filozofskog Fakulteta u Zadru 40/27, 2003, $29-48$.

Delev, P. 'The Burning of the Temple at Delphi, the Roman Governor L. Scipio and the Rout of the Scordisci', in A. Rufin Solas (ed.), Armées grecques et romaines dans le nord des Balkans. Conflits et Integration des Communautes Guerrieres. Akanthina 7, Gdánsk \& Toruń: Foundation Traditio Europae, 2013, 91-103.

Dobiáš, J. Studie k Appianově knize Illyrské, Prague: Naklada Filosofické fakulty University Karlovy, 1930.

Domić-Kunić, A. 'Literarni izvori za iliričke provincije (Dalmaciju i osobito Panoniju) u Naturalis Historia Plinija Starijeg', Vjesnik Arheološkog muzeja u Zagrebu, ser. III 37, 2004, 119-171.

Dueck, D. 'The Geographical Narrative of Strabo of Amasia', in K. A. Raaflaub and R. J. A. Talbert (eds.), Geography and Ethnography: Perceptions of the World in Pre-Modern Societies, Malden MA/Oxford/Chichester: Wiley-Blackwell, 2010, 236-251

Dzino, D. 'Welcome to the Mediterranean semi-periphery: The place of Illyricum in book 7 of Strabo', Živa antika 56, 2006, 113-128.

. 'Strabo 7, 5 and imaginary Illyricum', Athenaeum 96(1), 2007, 173-192.

. Illyricum and Roman Politics 229 BC-AD 68, Cambridge: Cambridge University Press, 2010.

'Illyrians' in ancient ethnographic discourse', Dialogues d'Histoire Ancienne 40(2), 2014, 45-65.

'Constructing Illyrians: Prehistoric inhabitants of the Balkan Peninsula in the early modern and modern perceptions', Balkanistica 27 (2014a), 1-39.

Evans, R. 'The cruel sea? Ocean as boundary marker and transgressor in Pliny's Roman Geography', Antichthon 39, 2005, 105-118.

Foucault, M. Power/Knowledge: Selected Interviews and Other Writings 1972-1977, ed. C. Gordon, London: Pantheon Books, 1980. 
Gómez Espelosín, F. J. ‘Appian’s Iberike. Aims and attitudes of a Greek historian of Rome’, ANRW, 2.34.1, 1993, 403-427.

Gowing, A. The Triumviral Narratives of Appian and Cassius Dio, Ann Arbor: University of Michigan Press, 1992.

Gračanin, H. 'Illyricum of the $2^{\text {nd }}$ and $3^{\text {rd }}$ centuries $\mathrm{AD}$ in the works of Latin and Greek historians', in: M. Šegvić, I. Mirnik (eds.), Illyrica Antiqua. Ob honorem Duje Rendić-Miočević, Zagreb: FF Press, 2005, 287-298.

Hahn, I. and Németh, G. ‘Appian und Rom', ANRW, 2.34.1, 1993, 364-402.

Katičić, R. Illyricum Mythologicum, Zagreb: Antibarbarus, 1995.

Kovács, P. A History of Pannonia during the Principate, Abhandlungen zur alten geschichte 65, Bonn: Dr Rudolf Habelt GmbH, 2014.

Kozličić, M. Historijska geografija istočnog Jadrana u starom vijeku, Split: Književni krug, 1990.

Krebs, C. B. 'Imaginary geography in Caesar’s Bellum Gallicum', AJPh 127, 2006, 111-136.

Lund, A. A. 'Versuch einer Gesamtinterpretation der "Germania” des Tacitus, mit einem Anhang: Zu Entstehung und Geschichte des Namens und Begriffs "Germani”'; 'Kritischer Forschungsbericht zur “Germania” des Tacitus', ANRW 2.33.3, 1991, 1858-2222.

Malkin, I. 'A Colonial Middle Ground: Greek, Etruscan and Local Elites in the Bay of Naples', in C. L. Lyons, J. K. Papadopulos (eds.) The Archaeology of Colonialism, Los Angeles: Getty Research Institute, 2002, 151-181.

Marasco, G. 'L’Illyriké di Appiano', ANRW, 2.34.1, 1993, 463-495.

Marion, Y. 1998 'Pline et l'Adriatique orientale: quelques problèmes d'interpretation d'Histoire Naturelle 3.129-152', in: P. Arnaud and P. Counillon (eds.), Geographica Historica. Ausonius Études 2, Bordeaux/Nice: Ausonius, 1998, 119-135.

. 2006 'Strabon et l’Illyrie. Essai de cartographie’, in S. Čače, A. Kurilić, F. Tassaux (eds.) Les routes de l'Adriatique antique. Ausonius Éditions 16, Bordeaux/Zadar: Ausonius/Sveučilište u Zadru, 2006, 31-38.

Matijašić, I. "Shrieking like Illyrians": Historical geography and the Greek perspective of the Illyrians in the $5^{\text {th }}$ century BC', Arheološki Vestnik 62, 2011, 289-316.

., 'Geografia del mondo Illirico tra v e iv secolo a.C.', in Y. Marion and F. Tassaux (eds.), AdriAtlas et l'histoire de l'espace adriatique du VI ${ }^{e}$ s. a.C. au VIII ${ }^{e}$ s. p. C., Ausonius editions: Scripta Antiqua 79, Bordeaux: Ausonius 2015, 131-148.

Mitchell, S. "Ethnicity, Acculturation and Empire in Roman and Late Roman Asia Minor", in S. Michell and G. Greatrex (eds.), Ethnicity and culture in late antiquity, Swansea: Classical Press of Wales, 2000, 117-150

Mlekuž, D. 'Who were the Cyclopes? Odyssey and Neolithic, Eneolithic and Bronze Age pastoralists from the east Adriatic coast and Dinarides', in: M. Blečić, M. Črešnar, B. Hänsel, A. Hellmuth, E. Kaiser, and C. Metzner-Nebelsick (eds.), Scripta praehistorica in honorem Biba Teržan. Situla 44. Ljubljana: Narodni muzej Slovenije, 2007, 69-82.

Nicolet, C. Space, Geography and Politics in the Early Roman Empire, Ann Arbor MI: University of Michigan Press, 1991.

O’Gorman, E. 'No place like Rome: identity and difference in the Germania of Tacitus', Ramus, 22, 1993, 135-154.

Osgood, J. 'The pen and the sword: writing and conquest in Caesar's Gaul', ClAnt 28(2), 2009, 328358.

. 'Breviarium totius imperii: The background of Appian’s Roman History', in: Welch 2015, 23-44.

Ørsted, P. Roman Imperial Economy and Romanization, Copenhagen: Museum Tusculanum Press, 1985. 
Papazoglu, F. The Central Balkan Tribes in pre-Roman Times, Amsterdam: Hakkert, 1978.

Popović, P. ' ...c cum a Scordiscis Dacisque premeretur', in: H. Dobrzańska, W. Megaw and P. Poleska (eds.), Celts on the Margin: Studies in European Cultural Interaction VII c. BC - I c. AD dedicated to Zenon Woźniak, Kraków: Institute of Archaeology and Ethnology of the Polish Academy of Sciences, 2005 77-83.

Potter, D. Literary Texts and the Roman Historian, New York: Routledge, 1999.

Powell, A., Welch, K. (eds.) Julius Caesar as Artful Reporter: The War Commentaries as Political Instruments, London/Swansea: Duckworth/Classical Press of Wales, 1998.

Purcell, N. 'The Creation of a provincial landscape: The Roman impact on Cisalpine Gaul', in T. Blagg and M. Millett (eds.), The Early Roman Empire in the West, Oxford: Oxbow Books 1990, 7-29.

Rich, J. 'Appian, Polybius and the Roman's war with Antiochus the Great: A study in Appian’s sources and methods', in Welch 2015, 65-124.

Riggsby, A. M. Caesar in Gaul and Rome: War in Words, Austin: University of Texas Press, 2006.

Riva, C. 'Ingenious Inventions: Welding Ethnicities East and West', in: S. Hales and T. Hodos (eds.) Material Culture and Social Identities in the Ancient World, Cambridge: Cambridge University Press, 2010, 79-113.

Rossignoli, B. L'Adriatico greco. Culti e miti minori, Rome: “L'Erma” di Bretschneider, 2004.

Rutledge, S. H. 'Tacitus in tartan: textual colonization and expansionist discourse in the Agricola', Helios 27(1), 2000, 75-95.

Said, E. W. Orientalism, London: Routledge and Kegan Paul, 1978.

Salway, B. 'Travel, itineraria and tabellaria', in C. Adams and R. Laurence (eds.), Travel and Geography in the Roman Empire, London/New York: Routledge, 2001, 22-66.

Schadee, H. 'Caesar's construction of northern Europe: inquiry, contact and corruption in De Bello Gallico', CQ 58(1), 2008, 158-180.

Sterling, G. E. Historiography \& Self-definition: Josephos, Luke-Acts \& Apologetic Historiography. Supplements to Novum Testamentum 64, Leiden: Brill, 1992.

Šašel Kos, M. A Historical Outline of the Region between Aquileia, the Adriatic and Sirmium in Cassius Dio and Herodian, Ljubljana: Slovenska Akademija znanosti in umetnosti, 1986. . 'Cadmus and Harmonia in Illyria', Arheološki Vestnik 44, 1993, 113-136.

. 'Caesar, Illyricum, and the hinterland of Aquileia', in G. Urso (ed.), L'Ultimo Caesare. Scritti riforme progetti poteri congiure. Atti del convegno internazionale Cividale del Friuli, 16-18 settembre 1999. Centro Ricerche e Documentazione sull'Antichità classica Monografie 20. Rome: Centro Ricerche e Documentazione sull'Antichità classica, 2000, 277-304.

. 'Mythological stories concerning Illyria and its name', in P. Cabanes, J.-L. Lamboley (eds.),

L'Illyrie méridionale et l'Épire dans l'Antiquité IV, Paris: De Boccard, 2004, 493-504.

. Appian and Illyricum. Situla 43, Ljubljana: Narodni muzej Slovenije, 2005.

. 'Pannonia or Lower Illyricum?', Tyche 25, 2010, 123-130

'Peoples of the northeastern fringes of the Greek world: Illyria as seen by Strabo', in J.-L. Lamboley and M.-P. Castiglioni (eds.), L'Illyrie méridionale et l'Épire dans l'Antiquité V, Paris: De Boccard, 2011, 617-629.

Talbert, R. J. A. 'Rome's provinces as framework for world-view', in L. de Ligt, E. A. Hemelrijk, and H. W. Singor (eds.), Roman Rule and Civic Life: Local and Regional Perspectives, Leiden: Brill, 2014, 21-38

Todorova, M. Imagining the Balkans, Oxford: Oxford University Press, 1997.

Welch, K. (ed.) Appian's Roman History: Empire and Civil War, Swansea: Classical Press of Wales, 2015.

Wilkes, J. J. Dalmatia, Cambridge Mass: Harvard University Press, 1969. 
Wiseman, T. P. 'Practice and theory in Roman historiography', History: The Journal of the Historical Association 66, 1981, 375-393.

\author{
DANIJEL DŽINO \\ Mekvari Univerzitet u Sidneju

\begin{abstract}
APIJANOVA ILIRIKA: POSLEDNJA FAZA U RIMSKOJ KONSTRUKCIJI ILIRIKUMA
\end{abstract}

\begin{abstract}
Rezime
U ovom radu se tvrdi da Apijanova Ilirika predstavlja poslednju fazu u rimskoj konstrukciji Ilirikuma tako što daje 'istorijsku biografiju' ovog područja - od mitološke prošlosti do rimskih osvajanja. Politika Apijanovog vremena oblikovala je nova viđenja carstva kao celovitog entiteta koji je trebalo da ostane baš takav kakav je bio u drugom veku, tako stvarajući nove mentalne obrasce za svoje stanovnike i intelektualnu elitu da bi mogli da percepiraju svet i svoje mesto u njemu. Stoga, ako se carstvo smatralo završenim delom, to viđenje je svakako povezivalo sve njegove delove, provincije i regije koje je stvorila rimska administracija. Promena u mentalnom obrascu promenila je društvenu stvarnost a književnici koji su pripadali intelektualnoj eliti carstva trebalo je da osete potrebu da je opišu. Baš ovo vidimo u Apijanovom nezadovoljstvu sa hronološkim pristupom istoriji u ranijoj grčko-rimskoj istoriografiji i u njegovoj konceptualnoj izjavi s početka Rimske istorije da on namerava da „opiše granice naroda kojima vladaju Rimljani“. U radu se raspravlja o nekoliko tema da bi se predstavio ovaj argument: razvoj termina 'Ilirikum' u rimskom političkom i književnom diskursu, raniji književni pokušaji da se ovaj region ujedini sa korpusom drevnog znanja, i književne i intelektualne strategije koje Apijan koristi da bi opisao ovaj region.

Apijanovu Ilirsku knjigu, kao i druge izvore iz grčko-rimskog perioda, napisao je pripadnik obrazovane mediteranske elite. 'Znanje' koje je on proizveo stvorilo je pogled na svet iz carskog centra gde je bila koncentrisana sva politička moć. U slučaju Ilirikuma njegovo delo opisivalo je društvenu stvarnost od potpune integracije jedne carske periferije, preko vojnih osvajanja i reorganizacije provincijskog pejzaža. Ono je dovršilo zadatak koji je započet u Cezarovo vreme da se racionalizuje rimska politička dominacija nad različitim zajednicama u regionu od Makedonije do severne Italije tako što će se taj prostor konstruisati kao nova geopolitička jedinica - Ilirikum. Ovo je olakšalo političko upravljanje regionom kad se rimska vladavina kasnije proširila prema Dunavu i nakon toga transformisala u provincije Dalmacije i Panonije. Apijan predstavlja celovitu sliku svom čitalaštvu kroz etnografski uvod. On definiše Ilirikum kroz dve različite percepcije 'drugog': grčku etnografsku percepciju, koja ustanovljava etnički termin 'Iliri', i rimsku kolonijalnu konstrukciju, koja dalje razvija grčku terminologiju i ovaj naziv koristi kao taksonomsko obeležje za politički dominiran prostor koji se nikako drugačije ne može definisati.

Apijan stavlja stanovnike Ilirikuma na prostorne i vremenske koordinate grčke mitološke prošlosti opisujući pred-rimsku prošlost i rimsko osvajanje kao 'pravednu' kaznu za bogohulne napade na Delfe. On je pokušao da premosti jaz između različitih konteksta i različitih Ilirikuma koji su postojali u njegovoj prošlosti i sadašnjosti, a da istovremeno predstavi Ilirikum kao nepromenjivu jedinicu. Ono što jeste uradio je stvaranje 'istorijske biografije' Ilirikuma tako što je ovu jedinicu projektovao na prošlost u potrazi sa njegovim nastankom, njegovim mitskim precima i najranijom prošlošću, a završava sa opisom rimskih osvajanja koja su u ovo područje donela 'civilizaciju'. Apijanov Ilirikum je napravljen na sličan način kao Strabonovo delo - od delova različitih prošlosti, spojenih u celinu snažnom silom rimske carske ideologije. Za razliku od Strabona, Apijanov Ilirikum
\end{abstract}


ne maršira prema civilizaciji; to je region koji je u potpunosti uključen u rimsku mrežu ideologije nova 'zamišljena zajednica' koja objedinjuje sve raznolike lokalne istorije i geografije pod jedan carski kišobran.

Ključne reči: Apijan, Ilirik, Rimsko carstvo, imperijalna geografija.

(C) Faculty of Philosophy, Novi Sad, 2016

ISTRAŽIVANJA - JOURNAL OF HISTORICAL RESEARCHES 27, 69-83 